\title{
Nursing to combat the COVID-19 pandemic
}

Francisca Valda da Silva'

ORCID: 0000-0002-6364-2241

'Retired professor at the Universidade Federal do Rio Grande do Norte. Doctor Honoris Causa at the Universidade Federal do Rio Grande do Norte. National Health Counselor. Coordinator of the Comissão Intersetorial de Recursos Humanos e Relações de Trabalho do Conselho Nacional de Saúde. President of ABEn Nacional - Administration from November 2019 to June 2020. Brasília, Federal District, Brazil.

How to cite this article: Silva FV. Nursing to combat the COVID-19 pandemic. Rev Bras Enferm. 2020;73(Suppl 2):e2020sup2. doi: http://dx.doi.org/10.1590/0034-7167-202073suppl201
Worldwide, the countries that have achieved the best results in combating the COVID-19 pandemic are those that have made social isolation; guaranteed health care for the population, in a sanitary and human emergency; increased the number of hospital beds and ICUs; carried out massive tests on their population; and took measures to maintain income and activate the economy. There is no dichotomy between saving lives and maintaining economic activity.

Against the civilized world, the hard core of the federal government chose to listen only to big businessmen, however, with arrogance, it started to defend only vertical isolation restricted to the elderly population and with comorbidities as an effective measure to contain the advance of coronavirus.

The circulation of large contingents of people in environments totally favorable to the spread of the virus (SARS-CoV-2) is contrary to Law 13,979/2020. This law was signed by the president, which establishes measures to deal with the public health emergency of international and national importance resulting from COVID-19. It aims to protect the community and reduce the speed of transmission of the disease so that the available health services are able to serve all people with severe symptoms of the disease.

The speech of the President of Brazil poses a false issue for the population: facing the health or economic crisis to justify his choice to defend the strictly economic interests that will lead to the deepening of social exclusion with the logic of "sanitary hygiene" of people considered "disposable". They are those who are below the poverty line, at high risk and with social vulnerability. This is a group at risk to enter the statistics of an exponential growth of the pandemic by COVID-19 in Brazil, in April, and which will become part of alarming disease and death statistics. We can stop the chain of transmissibility of the virus (SARS-CoV-2), stay at home!

It is a genocidal plan and repudiated by ABEn. How many health professionals on the front line of direct assistance, who are at risk, will fall ill and die from the cases that this irresponsible discourse has the potential to produce? Statistics show that it is $8 \%$, but that is not all! It is the option to reduce the time of the evolution curve of human infection with Coronavirus, to protect the economy, even if it means explosive growth of cases and lack of assistance. It is the State's lack of responsibility and the liberation of save yourself if you can.

How many people will enter the work with the inconsequent thought of comparing COVID-19 to a "flu" or a "cold"? How many people will be without treatment condition by SUS, exposing workers even more? And what about all the people? It is not only the logic of the necropolitics, it is talked about the murder of workers who are at the forefront of health services in defense of the population, as is the case of nursing; about 2 million professionals (nurses, assistants and nursing technicians) face to face with coronavirus, on the front to combat COVID-19. It is a topic of social relevance on health work. This speech by the President of the Republic will kill professionals who try to save their lives, and this is terrifying! We have to further mobilize our networks, the press and the general population to protect health professionals. 
The ABEn Network (National, and State and Federal District Sections) is placed, with the population and other bodies, alongside nursing professionals, so that they receive labor and social security protection from the State, in addition to the due guarantee of working conditions (inputs, adequate number of professionals per team for each shift, guarantee of a resting place, access to quality and sufficient PPE, etc.) for the correct and safe professional performance in the struggle for the health of the population and the right to life.
\#NursingDefendsLife \#NursingAgainstCoronavirus \#StrengthChallengesNursing \#ABEnDefendsSUS

\#RevokingEC95

\#SUSCombatsCoronavirus

\#TogetherWeWinCOVID-19 